\title{
Sick of It All
}

\author{
Jared Russell ${ }^{1}$
}

$\mathrm{I}$

$\mathrm{n}$ a brief statement concerning our current global crisis, made one month into the Covid-19 pandemic, the philosopher Bernard Stiegler invited us to regard confinement as a gift. Drawing on his own experience of confinement following his incarceration for a series of bank robberies in the late 1970s, Stiegler argued that confinement can provide us with a much needed opportunity for reflection, and to reconnect with practices of traditional care and education-practices everywhere threatened by the destruction of intergenerational connectedness. "Confinement," he wrote, "can revive the memory and meaning of past ways of life" $(2020,2)$. His hope appears to have been that in confinement and quarantine we might find the ability to think again, and to rethink what it means to be able to be and to do things together.

Four months later, Stiegler killed himself. Apparently he was very sick, with an unspecified illness for which he had long been undergoing extensive hospitalization. But in his late writings, he had also increasingly become open about a lifetime spent struggling with depression and suicidality. Having written so extensively from a contemporary Nietzschean perspective, Stiegler must have known that his final decision and gesture would not be taken lightly by those familiar with his thinking.

It must also not have escaped Stiegler that his suicide following a period of protracted, uncircumventable illness would be a repetition of the final gesture of another great French Nietzschean philosopher: Gilles Deleuze. Deleuze spent the last years of his life like so many Americans today: on a ventilator. Eventually he threw himself out a window.

I was living in Paris as a student of philosophy when Deleuze committed suicide. He had spent his career, like Stiegler, criticizing the intrinsically suicidal tendencies of our contemporary world. I still have my copy of the French newspaper InfoMatin from that day, which announced on its cover, alongside his photo, "Gilles Deleuze définitivement hors système." I've always thought that headline was hysterically funny, and that Deleuze would have thought so, too.

But the headline missed the point of Deleuze's work, which was also consistently Stiegler's point, because it was central to Nietzsche's thought: The world today is one in which there is no "outside the system," in which there is no vantage point from which to resist this suicidal trajectory in which we are all killing ourselves-with education that isn't really education, culture that isn't really culture, and with a form of politics that no longer resembles anything like politics at all. This is what Nietzsche called nihilism. This is the

${ }^{1}$ Jared Ruseell, Ph.D., is a psychoanalyst in private practice in New York City, United States. E-mail: admin@tplondon.com 
illness of our age, of which the Covid-19 pandemic is only a minor symptom. "Sickness itself," Nietzsche wrote, "is a kind of ressentiment" (1967, 230).

When Nietzsche scholars remind us that nihilism is, "the radical repudiation of value, meaning, and desirability" (1968, p.7), merely rehearsing Nietzsche's words within an academic context, they fail to see just how prophetic Nietzsche was in anticipating the moment through which we are currently living, and the world towards which we are inescapably headed. Nihilism, which means that human beings "rather will nothingness than not will" $(1967,97)$, is a form of absolute madness. It is psychosis, and no psychosis ever recognizes itself as such. It is an illness that relentlessly feeds off of itself in an ever accelerating way to the point of destroying itself in an absolutely spectacular fashion ("Nothing burns one up faster than the affects of ressentiment. Anger, pathological vulnerability, impotent lust for revenge, thirst for revenge, poison-mixing in any sense... such affects involve a rapid consumption of nervous energy" (1967, 230)). No philosopher could be more pertinent to our time than Nietzsche because we are far down this road into illness, as demonstrated by the fact that for most people, caught up as they are in their own self-destructive behaviors, this decline is virtually unwitnessable. Trump, who promises to make us "great again," and Biden, who previously ran under the simple banner of "hope," offer no solutions whatsoever to the real illness from which we are all now suffering, which is that of rushing headfirst into having no future at all.

The week I sat down to write this essay began with massive outrage over a "viral" video of an unarmed man being shot in the back seven times at point blank range in front of his children by a police officer. The monstrous injustice of this act aside, what was so striking was that this occurred in the middle of months of unrest that began with the murder of George Floyd, and soon after that the murder of Rayshard Brooks-events which were themselves captured in videos that also quickly went viral. In no way did the officer who shot Jacob Blake grasp in advance that his act too would obviously be filmed and go viral, making a terrible situation even worse, escalating tendencies towards murderous rage which he himself had instanced by going absolutely mad in that moment, pulling the trigger seven times at point blank range. This unbridled mania is part of what Nietzsche meant by nihilism.

The next night it is reported that the riots in Kenosha, Wisconsin-which follow this new viral incident, but which are part of a greater historical process - have finally produced the first murders committed by civilians against other civilians. At first it is not clear what this involves, or to which side the perpetrator belongs. Then it is announced that a seventeenyear-old boy with an assault rifle who dreamt of one day becoming a police officer has been arrested and is charged with two counts of intentional homicide. He is part of a group of armed citizens who had come from out of state to protect private property, hoping to assist trained adults who were incapable of doing so themselves.

As cell phone videos of the events that took place in Kenosha begin to emerge and to circulate, the chubby child who identified with the law-but in such a way that allowed him to act out his violent fantasies - and the group to which he belongs are aggressively denounced over the ensuing hours as "virulent" racists. The New York Times constructs a narrative of events based on these videos, and the article it publishes generates a comments section-which at this moment has drawn over 1300 responses, indicating a much vaster, widespread readership — in which virtually everyone denounces the violence of the right and 
sees racism as the greatest illness of our time. No one questions the perspective they have internalized; instead they proudly announce their conviction that it would be crazy not to see that it is the other side that is to blame. Mistaking the symptom for the illness is a part of the illness that Nietzsche called nihilism.

As all of this transpires, nightly television programming is dominated by the spectacle of the Republican National Convention, in which an illiterate gameshow host and his followers insist that this increasingly violent world over which he presides can be blamed on his opponent, and that the only cure for this violence is his reelection, because what is happening now threatens to become the future and to spread virally everywhere as it has under his own administration, for which he assumes no responsibility. He promises to cure us of society's ills, just as he had cured us of the spread of Covid-19, which is treated as a thing of the past, as the death toll rises quickly towards 200,000. Each of his children attests to the magical powers of their father, captivating viewers. This tendency towards captivation is also an aspect of what Nietzsche called nihilism.

Nietzsche understood that the future would be extremely violent, and we must no longer ignore him on this matter by treating him as a subject of mere scholarly research. Doing so is itself a part of the illness that he called nihilism, and we should begin using this word beyond academic discourse in order to honor Nietzsche's prophetic understanding:

One day my name will be connected with the memory of something tremendous, — a crisis such as the earth has never seen. $(1967,326)$

Nietzsche dreamt of a tremendous crisis. We are currently in the midst of several crisesepidemiological, economic, political, environmental-but none yet of the magnitude of which Nietzsche dreamt. An all-encompassing, singular crisis to which all dimensions of life would be subordinated. Great crises demand great reorganizations of values, ethics and life; and only great crises are capable of achieving this. We are certainly in the midst of a series of crises that demand thoughtful and active response, but for Nietzsche these would appear comparatively minor crises. They still fall far short of the "something tremendous" that Nietzsche foresaw and of which he tried to warn us.

Donald Trump also likes to use this word — tremendous - to describe his politics, which are not a politics in any meaningful sense of the word, no more so than those of his opponents. I don't think we should fret over the outcome of the election in November, because it is clear that, either way it falls, the effects will eventually be tremendous, until we are all living in Nietzsche's dream - the one he could not wake up from for the last eleven years of his life. Trump uses "tremendous" as a term of overwhelmingly positivity, indicating unsurpassed achievement. Nietzsche's use of the term is, obviously, significantly more nuanced, but I am no longer convinced that their respective uses of the word do not indicate much the same future. Nietzsche's tremendous finds no correlate in our world today, but I am increasingly convinced that it will, and very soon.

Nietzsche did not need to live through a global pandemic to see that the world is sick. From austere, Apollonian quarantines emerge Dionysian riots. Still this is not great crisis. Is a sick world capable of great crises? Can what is occurring right now in our streets be directed towards what Nietzsche called the constitution of new ideals? What would the vehicle of such a project consist in? A call for unity, or a call for greater and greater 
contradiction and conflict? Are we right to believe that the exacerbation of conflict can only lead to the further breakdown of law and order, or would a more robust commitment to breakdown provide the conditions for the establishment of a new order, which is to say something other than order in the ordinary sense?

I contradict as nobody has ever contradicted before, and yet in spite of this I am the opposite of a nay-saying spirit. I am a bearer of glad tidings as no one ever was before; I am acquainted with incredibly elevated tasks, where even the concept of these tasks has been lacking so far; all hope had disappeared until I had come along. And yet I am necessarily a man of disaster as well. Because when truth comes into conflict with the lies of millennia there will be tremors, a ripple of earthquakes, an upheaval of mountains and valleys such as no one has ever imagined. The concept of politics will have then merged entirely into a war of spirits, all power structures from the old society will have exploded-they are on based on lies: there will be wars such as the earth has never seen. Starting with me, the earth will know great politics - $(1967,327)$

Great politics, for Nietzsche, correspond to the appearance of tremors-premonitions of the coming of the tremendous. In public discourse we wring our hands over the appearance of still minor tremors that have no chance of bearing the weight of the tremendous, failing to project our political imagination over the course of millennia, narrowly focusing instead on the incessant "virtue signaling" intrinsic to "identity politics." There is no shortage of horrors we can point to since Nietzsche first described the coming age of nihilism. But perhaps what Nietzsche envisioned of himself as a bearer of glad tidings was something horrifying in its capacity to compel us together and to interact in new ways. Perhaps Nietzsche envisioned a form of unity so provocative of absolute horror that it would put the horror of the breakdown of law and order (dikee) to shame (aidos).

The prophets of this contemporary era of manic nihilism-like all true prophets-were the young. The school shooters, who appeared before the explicitly politicized events of September 11th, 2001, as the original jihadi of nihilism: Wayne Lo of Simon's Rock College in Great Barrington, Massachusetts; Dylan Klebold and Eric Harris of Columbine High School in Colorado; Kip Kinkel of Thurston High in Springfield, Oregon; so many others. These were the initial tremors of the world in which we currently find ourselves, appearing before-hopelessly before- the inevitable conjunction of their gestures and the horizon of contemporary politics. These efforts at what Stiegler (2009) had called the passage to the act-the attempt to feel that one is genuinely alive for once through acts of unbridled destructiveness, and from out of a pervasive sense that life is not life because it is not worth living — had already communicated the message that has increasingly come to define what is emerging as our future horizon: a war of all against all, a "war of spirits," but spirits struggling to become spirits, which is to say to feel alive and worthy of a life worth living, by committing acts of absolute violence. This is increasingly what is becoming of politics today in the Trump era. Even before the advent of the internet, these acts went "viral" and became more and more frequent, indicating what is truly at stake in the dynamic of what we have come to accept today as ordinary, pervasive virality, which is an illness. This mad, viral dynamic is intrinsic to what Nietzsche called nihilism. 
Watching our world unfold virally before us across screens of all kinds, we are all today like Nietzsche watching a horse being beaten by its carriage driver in Turin, and this is the case whether we know it or not. Like Stiegler and Deleuze- - and like Sarah Kofman, who commemorated the 150th anniversary of Nietzsche's birthday by committing suicide herself on that day-we will endure our illness until eventually we will collectively and spectacularly decide to bring everything to an end. Unlike Hegel, who thought the owl of Minerva flew only at dusk, Nietzsche understood that great thinkers demonstrate an uncanny ability to foresee the future well before anyone else.

August 29, 2020

\section{References}

Stielger, B. (2009). Acting Out. Trans. D. Barison, D. Ross and P. Crogan. Stanford, CA: Stanford University Press.

Stiegler, B. (2020). "Covid 19: Insight from the Angle of Memory." Trans. D. Ross. https://www.academia.edu/42827840/

Nietzsche, F. (1967). On the Genealogy of Morals and Ecco Homo. Ed. and Trans. W. Kaufman. New York: Vintage Books.

Nietzsche, F. (1968). The Will to Power. Ed. and Trans. W. Kaufman. New York: Vintage Books. 
30 Sick of It All

Jared Russell, Ph.D., is a psychoanalyst in private practice in New York City. He is a Fellow of the International Psychoanalytic Association, and a faculty member and clinical supervisor at several analytic training institutes. He is the author of Nietzsche and the Clinic: Psychoanalysis, Philosophy, Metaphysics (Routledge 2017) and Psychoanalysis and Deconstruction: Frend's Psychic Apparatus (Routledge 2019). 